\title{
Boards of Directors' Characteristics and Firm Value: A Comparative Study between Egypt and USA
}

\author{
Wafaa F. Salem, Saad A. Metawe, Amr A. Youssef, Mohamed B. Mohamed \\ Arab Academy for Science, Technology and Maritime Transport, Alexandria, Egypt \\ Email: wafaa.salem133@yahoo.com
}

How to cite this paper: Salem, W.F., Metawe, S.A., Youssef, A.A. and Mohamed, M.B. (2019) Boards of Directors' Characteristics and Firm Value: A Comparative Study between Egypt and USA. Open Access Library Journal, 6: e5323.

https://doi.org/10.4236/oalib.1105323

Received: March 10, 2019

Accepted: April 13, 2019

Published: April 16, 2019

Copyright $\odot 2019$ by author(s) and Open Access Library Inc.

This work is licensed under the Creative Commons Attribution International License (CC BY 4.0).

http://creativecommons.org/licenses/by/4.0/

\begin{abstract}
Purpose This research aims to compare the effect of board of directors' characteristics on the firm's value in Egypt as an emerging country and USA as a developed country. Five characteristics have been exposed from the literature review that may influence the enhancement of a firm's value. In corporate governance, these characteristics are CEO duality, board independence, board size, board meetings and gender diversity. Design The model is developed and 84 Egyptian firms listed on the Egyptian stock exchange and 27 American firms listed on The Dow Jones Industrial Average (DJIA) are utilized in this research for testing this model. The research covers a six-year period (2012-2017). Five main hypotheses and ten sub-hypotheses were derived from the model. GLS regression is used to test these hypotheses. Findings The results of this research revealed that board of directors' characteristics affects firm value almost in the same way in both Egypt and the USA. The results revealed that board independence, board meetings and gender diversity are positively and significantly related to firm value in both countries. Furthermore, it displayed that board size affected firm value in both the Egyptian and American contexts negatively and significantly. Finally, the results showed that the CEO duality has a positive effect on firm value in the Egyptian setting while it has a negative effect on the firm value in the American setting. This research contributes to the literature on the subject of how corporate governance enhances a firm's value. Participants in the stock market would benefit from the results when assessing the board of directors' roles in enhancing the firm's value. Regulators will be able to use the results of this research to recognize the critical characteristics of corporate governance and to assess the governance practices of the board of directors.
\end{abstract}




\section{Subject Areas}

Accounting, Corporate Governance, Entrepreneurship

\section{Keywords}

Corporate Governance, Board of Directors' Characteristics, CEO Duality, Board Independence, Board Size, Board Meetings, Gender Diversity, Firm Value

\section{Introduction}

Corporate governance is taken into consideration as an emerging topic related to firms globally because of the prevalence of corporate failures and economic crises. Besides defining and explaining corporate governance, many researches were stressing the advantages of corporate governance. As an example, it is shown in [1] that excellent corporate governance definitely implies the growth prospects of an economy. From the days corporate governance turned into a point of discourse, broad measure of research is directed on corporate governance in developed countries [2] [3] yet at the same time there is moderately little focus on some developing countries [4] [5]. In addition, relatively few researches have looked at cross-country diversities in corporate governance [6]. Beginning from this point, this research examines the degree of corporate governance varieties of a developed country (the United States) and a developing country (Egypt) through a definite comparative investigation of the impacts of board of directors characteristics on firm value of companies listed in stock exchange markets of each country. The research opens the door for an additional in-depth empirical study on why there are cross-country variations in corporate governance. A topic that is gaining growing attention from scholars of corporate governance is the study of the characteristics that the board of directors should own to ensure efficient management control and valued support in the decision-making process [3] [7]. In the companies, there could be significant conflicts among managers and shareholders, which could have an opportunistic behavior concentrating towards gaining personal benefits, which lead to higher agency costs in the firms. For the reason that the company administrators have direct contact to the firm information linked to strategic management, reinforcing the board is a method to advance the management of the firm's resources and permits for the tracking of the CEO's activities. Different theories predict dissimilar effects of board characteristics on firm value, such as the agency theory, the stewardship theory and the resource dependence theory. Many researches have been carried out on the impact of the corporate governance on the firm value, arriving at different results. As a rule, even though previous studies supported the prevailing theories, they similarly display contradictory proof concerning the relationship between a portion of the board of directors' characteristics and the firm value. 
In recent years, the studies on corporate governance have focused their attention on the analysis of the structure of the board [3] [7] [8] [9] [10] [11]. Yet, the empirical proof on the relationships among board structure and firm value is still uncertain. Many researches have been done on the impact of the corporate governance on the firm value, arriving at different results. A portion of these researches found that there is a positive relationship among board characteristics and firm value [12] [13], at the same time as different research discovered negative relationships among some variables of corporate governance and firm value [14] [15]. Different results, subject to the variables used to study the corporate governance, econometric methodologies, sampling techniques, study periods, and institutional arrangements that the varied researchers study [7]. Despite the large number of empirical studies on board of directors' characteristics and their impact on firm value, our knowledge in this area is far from perfect, especially in Egypt. The role of boards in Egypt and the impact of board characteristics on Egyptian firm performance have been investigated by a limited number of studies. Some of those are by [9] [16] and [17]. While an excessive deal of studies has been directed on corporate governance in the developed economies [2] [3] there is relatively little focus on the developing countries [4] [5] and even less focus on countries in the Middle East [18]. Furthermore, there are little comparative studies concentrating on diverse phases of economic development context [6]. Therefore, the US and Egypt were selected as the focus of this research. These two countries are representative of a developed economy (US) and a developing economy (Egypt). This, together with the rareness of the prior study in Egypt in this area, has led to trying to compare the effects of the board of directors' characteristics on the value of the Egyptian companies listed in the Egyptian Stock Exchange market as an emerging country with the effects of the board of directors' characteristics on the value of the American companies listed in the American stock exchange market as a developed country. Researchers focus in particular on five characteristics of the board of directors: Chief Executive Officer Duality, the presence of independent directors, the size of the board, the meetings of the board and its gender diversity. Consequently, this research is trying to answer the following main question: Do board of directors' characteristics affect firm value in the same way in both Egypt and the USA?

\section{Literature Review}

\subsection{Corporate Governance Definition}

Since the term corporate governance has come to light, corporate governance has been a widely discussed issue among the academics, the world business and the international organizations. Up till now, there is not a distinct mostly accepted definition of the corporate governance. There are, various authors and institutions (and even countries) that have given different definitions to corporate governance-the mutual meaning of which sum up the set of rules and codes that control the conflicts of interests and reinforce the relationships be- 
tween a firm's management, its board of directors, shareholders, and stakeholders [19]. Rezaee [20] defined it as a process that enables shareholders to encourage management to act in the shareholders' interests, hence providing a level of confidence to investors so that capital markets could function and control supplementary effectively. Additionally, Rahman [21] states that corporate governance is a group of processes, policies, customs, laws and institutions that affect the ways by which the corporations are managed and also controlled. The OECD (Organization for Economic Cooperation and Development) had been provided a definition that reflects the interests of both stakeholders and shareholders. This definition identified that the corporate governance is a group of relationships amongst the firms' management, their shareholders, their board and their other stakeholders. Corporate governance besides offers the structure that the objectives of the firms are set through it, and the methods of achieving those objectives and monitoring performance are dogged [22].

\subsection{Corporate Governance Evolution in Egypt and the USA}

By reviewing the evolution of corporate governance in Egypt and in US it can be noticed that, from the 1930's several regulations concerning corporate governance have been done in the US, the Securities Act of 1933 and the Securities Exchange Act of 1934 have been viewed as the first regulations about corporate governance, followed by FCPA (Foreign Corrupt Practices Act) in 1977, which had been the only regulation all over the world for the following 20 years. The current improvement concerning corporate governance is the Sarbanes-Oxley Act of 2002. This act not only intensely reformed the regulatory setting for corporations that share in the US capital market, but similarly posh other countries all over the world. By this act, the US Congress imposed major corporate governance and disclosure modifications and formed a completely new regulatory system for the accounting work, amongst other things. Whereas, till the late 90s, corporate governance was a novel term in Egypt, formerly the economic reform program happening. Numerous efforts have been applied by several institutions in Egypt containing the CMA (Capital Market Authority), Central Bank of Egypt, the EIOD (Egyptian Institute of Directors), the EFSA (The Egyptian Financial Supervisory Authority) and the Egyptian society of Accountants and Auditors to develop corporate governance in the Egyptian environment. At the end of 1990's, The Egyptian authorities revitalized its capital marketplace by refining its reputation and by means of growing investor self-confidence as a portion of its privatization program. As a result, the government found out that to reach such aspired desires, its corporate governance remained in requirement of an excessive-degree of improvement [16]. In 2005, the EIOD introduced the first release of Corporate Governance Code, essentially addressing listed companies to help them obey with governance and disclosure requirements, in the good interest of all shareholders and investors, moreover to help them to reach the maximum levels of efficiency and sustainability [23]. In 2006, the Ministry of 
Investment pronounced the Code of corporate governance for state-owned companies [24]. In the year 2011, a new ECCG (Egyptian Code of Corporate Governance) was issued modifying the first code and focusing on the listed companies and the financial institutions even if they are not listed [25]. In August 2016, the EIOD issued a new ECCG. The new ECCG applied to all listed and unlisted companies, banking and non-banking financial institutions, industrial, commercial and service companies, regardless of their size and nature of activity, whether they are family firms, or publicly owned [23].

\subsection{The Corporate Governance Theoretical Perspectives}

This section provides an overview of four theoretical perspectives that relate boards to corporate governance. The ones four theories are: the agency theory; the stakeholder theory; the resource dependence theory; the stewardship theory. These theories were put forward to present a higher knowledge and analysis of corporate governance.

The Agency Theory: This theory is regarded as the essential reference for all different theories associated with company governance. The roots of the agency theory arose somewhere at some stage in the 18 century. Adam Smith [26] one of the first to talk about company idea, demonstrated the hassle of separating ownership and control. Additionally, the agency theory become similarly developed by way of Jensen and Meckling [27] who defined the agency relationship as a settlement in which someone (the agent) is employed via the principal to execute numerous tasks on behalf of the most important, which encounters that authority has been delegated to the agent for some choice-making. Moreover, ensuring whether or not the agent is appearing towards the principal's good interest is an issue of problem. To clear up such a difficulty and restrict the discrepancy between the principal's interests and the agent's, and to align each in their interests, the fundamental ought to do two matters. The primary issue that could be completed is for the important to establish suitable incentives for the agent. Second, the principal should incur monitoring expenses that are designed to restrict the agent's abnormal activities [27]. Many managers are motivated by their very own private pursuits and blessings, these groups of the managers are typically less interested to track new profitable ventures. This is, consequently, particularly because of the battle of pursuits among the managers, in particular the ones who have higher understanding and information approximately the firm, and minority shareholders [28]. As an end result, diverse agency costs boom. Jensen and Meckling [27] assumed that defining the rights of every of the principal and the agent, by means of designing the best agreement conserving these rights, might assist the company remedy the enterprise problem. On this essence, numerous governance mechanisms were advised through exceptional research to tackle the organization trouble. Dealing with the board, as a governance group, emphasize many essential troubles, like the board size; executive or internal as opposed to nonexecutive or outside administrators; and isolating as 
opposed to unifying the CEO and the chair person. All those are geared toward ensuring powerful monitoring and oversight [29]. Coleman et al. [30] offered and summarized more than one methods that have a tendency to minimize opportunistic behaviors from an agent. The first is by means of having non-executive directors. To have an effective board of directors, agency theory proposes and expects that a big percent of the board must be allocated to non-executive directors. This, the theory asserts, guarantees the independence of the board, making certain a truthful and independent judgment in its tracking, thus lowering the struggle of interests among the managers and the shareholders. The second manner to decrease an agent's opportunistic behaviors is by what is referred to as a CEO duality. Agency theory stipulates that assigning the position of the CEO and the board chair to one-of-a-kind people reduces the probability that one person could impose his electricity on the firm's management and board contributors.

Resource Dependence Theory: It explains the corporate governance from a completely exclusive perspective. Developed by Pfeffer and Salancik [31], this approach strongly signifies the importance of resources greater than whatever else. This foundation considers the board to be one in every of several tools used to ease the get admission to of vital resources that could make a contribution to the firm's success. This perspective implies that the governance shape and the composition of the board are each regarded as resources that could assist boom the firm's value. Hillman et al. [32], stated that from the useful resource dependence view, outsider directors, bring resources to the firm, such as information, skills, access to the basic parts (e.g. investors, suppliers, social groups, public policy decision makers) and legitimacy. Furthermore, board directors have the capability to reveal knowledge obstacles, as a result enhancing the business potentialities. Board members commonly exercising outside hyperlinks, and they're engaged in networks that could undoubtedly have an effect on the enterprise improvement process in conjunction with its long-time period potentialities. In addition, Muth and Donaldson [33] signified the importance of community connections formed by means of outsider directors in improving the firms' performance. Accordingly, from the resource dependence theory view, the board is not only reflected a resource that alternates other resources, but it also pushes the environment in the direction of the firms favor, by this means improving firm performance.

Stewardship Theory: A unique view than that of the Agency theory is stewardship theory, which regards agents as trustworthy exact stewards of the company's resources, which makes monitoring seem redundant. From the stewardship theory point of view, directors and managers, being stewards of the firm, work with the intention of enhancing company overall performance and maximizing shareholders' wealth. They don't forget this a manner of boasting approximately the achievement and achievements of the management itself. Daily et al. [29] argued that managers and directors most possibly tend to be re- 
garded as talented choice makers, thinking about the company's overall performance a right away picture for his or her very own personal performance and recognition. On this regard, managers make certain that the company's operations obtain the finest financial performance, producing the maximum viable returns for shareholders. It proposes that there are also non-financial reasons that affect managers' choices. Those include a supervisor's inherent want for recognition and self-pride and their intrinsic respect for each work-ethic and authority. Coleman et al. [30] summarize the key factors that the stewardship theory takes into attention. The first is board size, which the theory encourages to be small for greater powerful communication and a smoother decision-making manner. The second one is the board of directors, in which the stewardship theory promotes firms to employ executive directors, for their involvement enhances the selection-making process and guarantees business sustainability. The third issue is the CEO duality. The stewardship theory recommends that the identical individual shall hold each positions; the CEO and the chairman of the board, as this activates faster CEO decision-making without the need to reporting the board of directors.

Stakeholder Theory: This theory is merely a ramification of the agency theory. The theory expects that a company's board of directors ought to be running inside the fine interests of its shareholders. This narrow consciousness has now been broadened in today's companies so that not only do boards work at the excellent interests of the shareholders, but they also understand that of the numerous stakeholders, this consists of social, environmental and moral businesses [34]. Thereby, stakeholder theory seems to add to agency theory; in fact, it assists in expanding the latter's slim scope. Moreover, the stakeholder theory argues that the board of directors need to now not only be concerned with shareholders' interests, however that extraordinary stakeholders' interests need to additionally be considered. Such issues might be social, environmental or moral [34]. Mitchell et al. [35] argued that a stakeholder is absolutely everyone who has one or all the following: influential energy over the company, a legitimate courting with the organization, or regular urge to say at the organization. In step with this typology, managers have to recollect and respond to exclusive types of stakeholders. It is able to be diagnosed then, from the stakeholder idea, that the choice-making process of a firm is affected and impacts it via many external groups.

To summarize what mentioned above, the agency theory particularly emphasizes how principals and agents have conflicting interests. The stewardship theory, in evaluation, sees managers as stewards to a company, and it sees that the interests of both the steward and the employer are in alignment. Instead, stakeholder theory delves into the predicament concerning how distinctive organizations of stakeholders have diverse interests. Finally, resource dependence theory highlights the importance of the board as a resource to the company, and it envisions a function beyond the traditional one (which sees the board as a controlling agent). 


\subsection{Board of Directors' Characteristics and Firm Value Literature}

This section will discuss the effects of corporate governance on firm value with a main focus on the characteristics of the board of directors and how it affects a firm's value.

\subsubsection{CEO Duality and Firm Value}

The preceding studies on the relationship between CEO duality and firm value is varied, some of it designate a positive relationship between the separation of decision management and decision control and firm value but the others find dissimilar results. In Egypt, Amer [9], in 56 firms listed on the Egyptian stock exchange tries to test how corporate governance improves a firm's financial performance in Egypt from (2004-2012), the results revealed that CEO duality are positively and significantly associated with the Tobin's Q. Hence, In Iran, Nashlaji and Ghanadi [10] targeted to examine the effect of the characteristics of the board of directors on financial performance (Tobin's Q) of corporations in Tehran Stock Exchange in 2015. The outcomes indicated that CEO duality had no effects on the firm performance (Tobin's Q). In light of the previous discussion, CEO duality invites more conflicts and reduces firm value and thus, the following hypothesis is developed:

$\mathrm{H1}$ : There is a significant negative relationship between CEO duality and firm value.

As the current research is a comparative study between Egypt and USA, and based on the preceding discussion the following sub hypotheses can be posit:

$\mathrm{H1a}$ : There is a significant negative relationship between CEO duality and the Egyptian listed firms' value.

$\mathrm{H} 1 \mathrm{~b}$ : There is a significant negative relationship between CEO duality and the American listed firms' value.

\subsubsection{Board Independence and Firm Value}

The word independent directors are comparable with outside directors [11]. Anderson and Reeb [12] and Muth and Donaldson [33] highlighted that the both of agency and resource dependency theories show a positive effects of independent directors on firm value in two dissimilar ways. In agency theory, independent directors control and monitor the management, reducing the agency costs. Nevertheless, conferring to the resource dependency theory, independent directors offers appreciated counsel to the CEO, enhancing the board's decision making. Jenwittayroje and Jiraporn [36] on a sample consisted of U.S. 20,632 firm-year observations from 1996 to 2014, they found that independent directors, significantly improved firm value measured by Tobin's Q during the Great Recession of 2008. Also, Asante-Darko et al. [37] in Ghana, found a positive but insignificant relationship amid the proportion of non-executive directors on the board and Tobin's Q. Hence, in Iran, Nashlaji and Ghanadi [10], found that independence of board of directors had a negative impact on the financial performance of companies (Tobin's Q). As revealed from the previous discussion, 
more board independence will ensure high value to the firm and thus, the subsequent hypothesis is as follows:

H2: There is a significant positive relationship between board independence and firm value.

H2a: There is a significant positive relationship between board independence and the Egyptian listed firms' value.

$\mathrm{H} 2 \mathrm{~b}$ : There is a significant positive relationship between board independence and the American listed firms' value.

\subsubsection{Board Size and Firm Value}

Outcomes on the effect of the board size on the firm value are differing. The literature submits that a large board size can have positive and negative effects: more monitoring against more stiff decision making. In Italy, Rubino et al. [7] in their study, found that the size of the board positively affects the value of non-family firms. However, In Egypt, Amer [9], in his study of how corporate governance improves a firm's financial performance in Egypt, found a negative and insignificant relationship between the board size and the Tobin's Q (firm value). In addition, Yermack [38] in his study of the American's firms finding negative relationships between the board's size and the firm value. Furthermore, Nguyen et al. [3] studied the impact of the board's size on the firm's value in Australia, via a large sample of the Australian firms from 2001 to 2011, they found a strong sign of negative relationship. Nevertheless, Coles et al. [39] found that the association between the firm's market value and the board size was inverted U-shaped, they challenge the assertion that boards with extra than seven to eight members are ineffective. Therefore, the hypothesis can be described as follow:

H3: There is a significant negative relationship between board size and firm value.

H3a: There is a significant negative relationship between board size and the Egyptian listed firms' value.

H3b: There is a significant negative relationship between board size and the American listed firms' value.

\subsubsection{Board Meetings and Firm Value}

Empirical literature and evidence about board meetings and firm value are differing. Many previous researches have revealed that meeting frequency offers numerous benefits to shareholders. The primary benefit is enabling extra time for directors to put and deliberate corporate strategies and monitoring the management [40]. In addition, meeting frequently decrease the degree of misunderstanding on the financial reporting practice and increasing the degree of transparency around the executive compensation practices and creates more regular earnings predictions [41]. Amer [9] in his study in Egypt found that the repeated board meetings in Egypt have a positive but insignificant effect on the firm financial performance measured by the Tobin's Q (firm value). Also, Vafeas [42] concludes that there is a positive link between the frequency of board meeting 
and financial performance, by studying a sample of 275 listed US firms from 1995: 2000. Nevertheless, Yermack [38] in a study that used a sample of 307 listed US firms from 1990 to 1994, found a significantly negative relationship between the frequency of board meetings and firm performance, as measured by Tobin's Q. Lastly, in a study done on a sample of listed Ghanaian firms from 2000 to 2005, Coleman et al. [30] presented that the frequency of board meetings has no relationship to financial performance.

H4: There is a significant positive relationship between Board meetings and firm value.

H4a: There is a significant positive relationship between Board meetings and the Egyptian listed firms' value.

$\mathrm{H} 4 \mathrm{~b}$ : There is a significant positive relationship between Board meetings and the American listed firms' value.

\subsubsection{Gender Diversity and Firm Value}

In latest years, scholars have started to study the effect of the existence of women in the board on the effectiveness of business decisions and their ability to effect firm performance [43]. The empirical results demonstrated mixed evidence. Many studies like [14] [44] realize a better capability to monitor managers' behavior in a mixed board. On this recognition, the existence of women directors could advance monitoring functions [44]. Also, Levi et al. [43] illustrate that the existence of women aids to generate shareholder value for the reason that they give the impression to be less dedicated to build economic empires, which in maximum cases are appreciated with the inefficient over consumption of corporate resources, and consequently permit firms to save resources that can be used in an investment projects that are extra profitable. A new study done by Terjesen et al. [45] based on a multi-theoretical justification concluded that female directors improve boards of directors' efficiency, particularly in line for to their innovation and creativity with reverence to problem solving. Nevertheless, Adams and Ferreira [14] found a negative relationship between the gender diversity of the board and company performance because of the over-monitoring conceded by women. There is a part of the literature didn't found any effects of gender diversity in the board of directors on the firm value [46]. Therefore, on the basis of these considerations, the following hypothesis can be formulated:

H5: There is a significant positive relationship between gender diversity and firm value.

H5a: There is a significant positive relationship between gender diversity and the Egyptian listed firms' value.

$\mathrm{H} 5 \mathrm{~b}$ : There is a significant positive relationship between gender diversity and the American listed firms' value.

\section{Research Methodology}

\subsection{The Research Design}

The positivism philosophy and the quantitative approach was adopted in this 
research. The appropriate issues essential for the design of the research process are assessed and organized into three sub-sections as follows:

\subsubsection{Research Variables' Definition and Measurement}

In this research, researchers will study the effect of the board of directors' characteristics (CEO duality, Board independence, board size, board meetings and gender diversity) as independent variables on the firm value (Tobin's Q) as a dependent variable and to evaluate clearly the effect of the governance variables, firm size, firm age, the financial leverage, sales growth, cash flows and industry type will be used as control variables as the following:

Dependent Variable: Firm Value: The Tobin's Q can be considered the classic valuation measure and has been frequently and broadly used in the literature of corporate governance to proxy the firm value (see for example, [5] [37] and [47]), Mentioning to these preceding studies the variable used to measure firm value is Tobin's $\mathrm{Q}$. The Tobin's $\mathrm{Q}$ ratio is a ratio devised through James Tobin, who hypothesized that the blended market value of all the companies on the stock marketplace must be about equivalent to the replacement costs of them. A low Tobin's Q (between zero and 1) means that the price to replace a company's assets is extra than the value of its stock. This infers that their stock price is undervalued. Conversely, an excessive Q (extra than 1) means that a company's stock is extra high priced than the alternative value of its assets, which means that the stock is overrated. Founded on Coleman et al. [30], Tobin's Q will be measured as the market value of equity and book value of total debts divided by book value of total assets.

Independent Variables: Board of Directors Characteristics: With the drive of test the research hypotheses, this study uses five variables to measure the board of directors characteristics, the sevariables definitions and how they will be measured in consistent with the preceding research are shown as the following:

CEO duality (DUAL), CEO duality is a situation where the role of the CEO of the firm and the chairman of the board are held by the same person. Following various studies, like those of [7] [8] [9] [10] and [48] this research will measure this variable by taking a value of 1 if the CEO and chairman are the same person; otherwise, that value will be 0 .

Board Independence (BOIND), a board of directors encompasses of two types of directors: executive and non-executive directors. Subsequent to several studies, such as: [7] [8] [9] [10] and [48] this research will measure the board independence as the ratio of non-executive directors over the total number of directors.

Board Size (BOSIZE), Subsequent to several studies, like those of [3] [7], and [9] this research will measure the board size variable by the total number of members who sit on the board of directors.

Board Meetings (BOMEET), board meetings are deliberated a critical indication of board attentiveness and a crucial portion of the board processes. Con- 
sequent to several studies like [40] [41], board meetings will measured by seeing how many meetings are annually held by the board of directors.

Gender Diversity (GENDIV), researchers have started to study the impact of the presence of the women in the board on the efficiency of the business decisions and their capability to influence corporate performance. Following many studies, such as: [7] and [46], this research will measure Gender diversity as the ratio of female directors over the total number of directors.

Control Variables: To assess clearly the effect of the governance variables, researchers include into the analysis six control variables: firm size, firm age, financial leverage, sales growth, cash flows and industry type.

Firm Size (FSIZE), is measured as the logarithm of total assets [3] [7]. Cheng [49] found that firm size have a significant positive relationship with Tobin's Q. However, Coles et al., [39], Nguyen et al. [3] and Amer [9] found a significant negative relationship between firm size and Tobin's $\mathrm{Q}$. So, we can predict a negative effect of firm size on firm value.

Firm Age (FAGE), succeeding to several studies, like [48], in this research Firm age will be measured by the logarithm of the number of years since its incorporation. Consequently to the uncertain relationship of firm age on firm value, in this research we will avoid predicting the direction of its effect on the value of the firm.

Financial Leverage (FLEV), is calculated as the total debt divided by the total assets of the firm [3] [7] and [48] Leveraged firms, as showed in many studies like Andres [50], are probable to have lower value. Consequently we expect a negative relationship between financial leverage and firm value.

Sales Growth (SG), taking into account the firm's growth opportunities and is measured by the ratio of sales growth. Sales growth are estimated to cause higher long-term profit [51]. Consequently we expect a positive relationship between sales growth and firm value.

Cash Flow (CF), is resulting from the ratio of cash flow from operations to total assets. Conferring to Dittmar and Mahrt-Smith [52] firms with more cash are likely to have higher value. High cash flow tolerates positive NPV projects to be financed and growth chance seized without needing external funding, consequently we expect a positive relationship between cash flow and firm value.

Industry Type (DIND), each industry has its special characteristics, which will directly influence the changes in firm value [53]. This study will control the industry type influence on firm value. It will be measured as Dummies for each of the main industries [53] [54]

\subsubsection{Sample Selection and Data Collection}

For Egypt, this research covers the Egyptian firms listed in the EGX for the period (2012-2017). This time period was designated for the reasons that: In March 2011, in quest of keep up to date with the best practices at the international and regional levels, in terms of the roles of Boards of directors, the EIOD revised the Corporate Governance Code for listed companies, in line with the governance 
guidelines at the time [17]. Consequently, this research will reveal the impact of the latest developments in corporate governance in Egypt on firm value from 2012 onwards. The sample ends in 2017 for the reason that this is the latest year for which the data was obtainable at the time through the process of data collection. By the end of 2017, 252 firms were listed in the Egyptian Stock Exchange Market. The research is limited to listed firms for the assumption that the listed firms follow the standards and rules set by the regulatory forms in the progression of their business actions. Furthermore, listed firms are likely to arrange and publish their financial information in obedience with the main accounting regulations. These corporations cover around twelve industries: chemicals, construction and materials, food and beverage, real estate, industrial goods and services and automobiles, personal and household products, travel and leisure, healthcare and pharmaceuticals, basic resources, telecommunication, oil and gas, and retail. Financial companies will not be included in this sample because they vary from the nonfinancial companies in their financial reporting characteristics and their governing tax requirements [55]. The sample is further reduced because only those firms whose financial statements and stock price are complete for the 2012 to 2017 period are included, leaving a final sample of 84 firms. Consequently, a final sample of 84 Egyptian listed firms was obtained for a period of six years. Corporate governance data for this sample collected from the annual board of director's reports and the financial statements for the years of the study.

For the USA, this research covers the American firms listed in the Dow Jones Industrial Average (DJIA) for the same period (2012-2017). The DJIA, is one of the most established and most popular indexes in the USA stock exchange that estimates the everyday estimation of the main 30 US firms that track USA stocks that are the main economy and listed on the NASDAQ and NYSE. The American sample firms for this study primarily contain all the 30 firms in The DJIA Index during the 6-year period from 2012 to 2017. Financial companies omitted from this index. The total number of firm-year observations after excluding the financial companies is 162 (27 firms). This sample covers around sixteen industries: Conglomerate, Information technologies, Pharmaceuticals, Food, Oil \& gas, Technology (Computer Systems), Industrials (Diversified Industrials), Chemical industry, Consumer goods, Construction and mining equipment, Aerospace and defense, Apparel, health care, Telecommunication and Broadcasting and entertainment. Financial data used in the study comes from the COMPUSTAT database, which contains thousands of annual and quarterly income statement, balance sheet, cash flow, pension, supplemental and descriptive data items for active and inactive companies throughout the world. Besides, the data is gotten from annual reports to complement any missing information. Next, information about the firms' board of directors is attained from the BoardEx database which encloses information on firms' boards and senior management.

\subsubsection{Regression Model of the Study}

To test the role of the board in determining firm value, the following empirical 
model will be applied.

$$
\begin{aligned}
\text { Tobin's Q } i, t= & \beta 0 i, t+\beta 1 \text { FISIZE } i, t+\beta 2 \text { FAGE } i, t+\beta 3 \text { FLEV } i, t \\
& +\beta 4 \text { SG } i, t+\beta 5 \mathrm{CF} i, t+\beta 6 \text { DIND } i, t+\beta 7 \text { DUAL } i, t \\
& +\beta 8 \text { BOIND } i, t+\beta 9 \text { BOSIZE } i, t+\beta 10 \text { BOMEET } i, t \\
& +\beta 11 \text { GENDIV } i, t+\mu i, t
\end{aligned}
$$

where: Tobin's Q: firm value, FISIZE: firm size, FAGE: firm age, FLEV: Financial leverage, SG: sales growth, CF: cash flow, DIND: industry type, DUAL: CEO duality, BOIND: Board Independence, BOSIZE: Board size, BOMEET: board meetings, GENDIV: gender diversity, $\mu$ is the error term., $i$ stands for firm, and $t$ stands for time.

This research tests the effect of multi corporate governance variables on the firm value as a dependent variable. Therefore, a multiple regression is considered to be proper for this research. Agreeing to Hutcheson and Sofroniou [56], the Ordinary Least Squares (OLS) regression is considered to be a dominant technique when the model contains both continuous and dummy variables, which is the case in this research. Nonetheless, the use of OLS regression is relying on certain assumption. So, researchers will test the data under study for some regression assumptions. Researchers will use Hausman test for fixed versus random effects, also, testing for normality to find out if the variables in the model have approximate normality or not. Furthermore, autocorrelation problem will be investigated using the Durbin-Watson test. In addition, researchers will test for multicollinearity which refutes the correlation between the explanatory variables. Finally, researchers will be use the White's test for heteroscedasticity to discover if heteroscedasticity exists. The statistical techniques assigned for this research were applied using the statistical package of EVIEWS-version 10. Based on the prior discussion, the GLS regression (Generalized Least Squares) chosen to examine the existence of a relationship between firm value and the characteristics of board of director's factors. Thus, GLS regression is more proper, especially in this research, because it corrects the omitted variable bias and the existence of autocorrelation and heteroscedasticity [57].

\subsection{Research Conceptual Framework and Hypotheses}

This study will fill the gap within the academic literature concerning the corporate governance in several ways. The primary one lies within the multi-theoretical framework furnished through this study, which identifies the diverse characteristics of the board of directors. Future research can use this framework as a foundation to accumulate empirical results on the effectiveness of boards. Second, this study will apprehend the boundary circumstances for diverse theoretical explanations concerning the relationship among board characteristics and firm value. Agreed with that the one size suits all approach has not verified to be very evocative in the setting of board composition, that specialize in this kind of multi-theoretical framework can assist in the understanding of large insights into the efficacy of different boards. Lastly, this study will provide 
empirical outcomes on the performance of boards in the Egyptian market as an emerging country compared by the performance of boards in the American markets as a developed country, which is essentially didn't explored in the literature. This research aims to fill the gap inside the academic research through specializing in the Egyptian and the American firms from 2012 to 2017. It does so by using secondary data and by analyzing the various characteristics of the board and seeing whether they have an impact on the firm's value or not. Consequently, an investigation of the mechanisms of corporate governance in Egypt would help in assessing whether or not the results of previous studies from round the arena might be implemented to Egypt or not. This study might give extra understanding and recommendations to have higher corporate governance practices in Egypt. The results of this study should be valuable, as it might be capable of becoming aware of what board characteristics are important to decrease the agency-related difficulties and enhance the company's overall value. On this regard, the role of CEO duality, the presence of independent directors, the size of the board, the board meetings, and the gender diversity in the board on firm value, examined as shown in the following conceptual framework, Figure 1.

In this research, five main hypotheses and ten sub hypotheses will be formulated and tested. The following Table 1 shows these hypotheses' statements.

\section{Results and Findings}

This research aims at comparing the effect of corporate governance on firms' value in Egypt as a developing country and USA as a developed country contexts. It is designed to test the effect of Board Characteristics (as one form of corporate governance) on Tobin's Q (as one form of firm value). As discussed before, a model was constructed to test the effect of Board Characteristics on the firm value and the results are presented here in this section, to answering the primary research question: Do board of directors' characteristics effect firm value in the same way on both Egypt and USA? Therefore, the current section discusses the empirical study for the current research. Accordingly, it shows the results and findings for the research using the statistical techniques assigned. These statistical techniques were applied using the statistical package of EVIEWS-version 10. The statistical techniques vary from simple descriptive analysis for the research variables to the model conducted for the effect of the independent variables on the dependent variable. In addition, the research hypotheses are tested using correlation analysis, simple regression analysis, and multiple regression analysis using GLS method. Moreover, testing some regression assumptions such as normality, autocorrelation, multicollinearity and heteroscedasticity, finally, the output of testing the research hypotheses and which hypotheses are supported and which are rejected is provided.

\subsection{Descriptive Statistics for the Research Variables}

This section deals with the descriptive statistics for the research variables through 


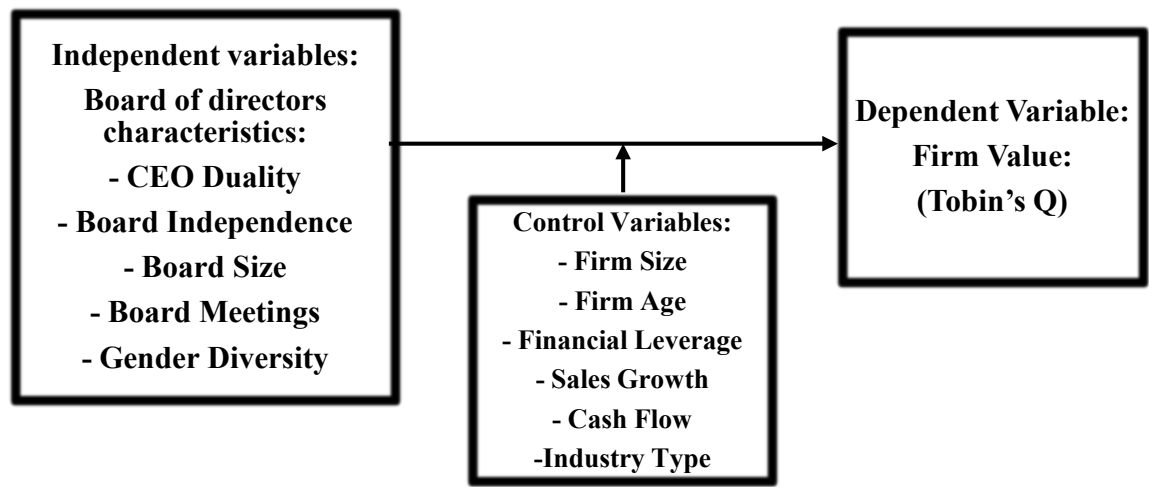

Figure 1. The conceptual framework of the study.

Table 1. Research hypotheses.

Board of Director's Characteristics and Firm Value Hypotheses

HI There is a significant negative relationship between CEO duality and firm value.

H1a There is a significant negative relationship between CEO duality and the Egyptian listed firms'value.

H1b There is a significant negative relationship between CEO duality and the American listed firms' value.

$\mathrm{H} 2$

There is a significant positive relationship between board independence and firm value.

H2a There is a significant positive relationship between board independence and the Egyptian listed firms' value.

There is a significant positive relationship between board independence and the American listed firms' value.

H3 There is a significant negative relationship between board size and firms value.

$\mathrm{H} 3 \mathrm{a}$

There is a significant negative relationship between board size and the Egyptian listed firms' value.

There is a significant negative relationship between board size and the American listed firms' value.

H4 There is a significant positive relationship between Board meetings and firm value.

$\mathrm{H} 4 \mathrm{a}$

There is a significant positive relationship between Board meetings and the Egyptian listed firms' value.

There is a significant positive relationship between Board meetings and the American listed firms' value.

H5 There is a significant positive relationship between gender diversity and firm value.

H5a

There is a significant positive relationship between gender diversity and the Egyptian listed firms' value.

There is a significant positive relationship between gender diversity and the American listed firms' value.

the data used in the analysis of this study. Some of the main features of the data is described quantitatively (e.g. measure of central tendency of the statistics, such as: mean, max and min; data dispersion, such as: range, variance, and standard 
deviation). Table 2 shows the descriptive statistics of the research variables of this study, where it could be observed that the average value for CEO Duality in Egypt is 0.6826 with a minimum value of 0 and maximum value of 1 . While this average value for CEO Duality in USA is 0.6667 , which means that $68 \%(0.67 \%)$ of the Egyptian (the American) sample had the chairman and the CEO held by the same person, which is against the corporate governance recommendation that the positions be split into two roles or, in other words, that the two roles should be held by two different people. Also, the average ratio for Board Independence in Egypt is 0.5811 with minimum value of 0 and maximum value of 0.93 . Which is higher slightly from the average ratio for Board Independence in USA ( 0.5332 with minimum value of 0.27 and maximum value of 0.88 ). This percentage highly complies with the corporate governance recommendations in which called for maintaining a board that is mainly composed of non-executive directors. In addition, the average ratio for Board Size in Egypt is 7.9657, with minimum value of 3 and maximum value of 15 . While the average ratio for Board Size in USA is 8 , with minimum value of 4 and maximum value of 11 , which is lower slightly from Bhagat \& Black [58] results, which have found that the mean size of the US boards is 11.45. Moreover, the average ratio for Board Meetings in Egypt is 10 times per year (mean $=10.0460$ ), which is exceeds the average ratio in USA (8.7111), and is highly exceeds the minimum number of meetings as recommended by the ECCG ( 4 times per year). Finally, the average ratio for Gender Diversity in Egypt is 0.0569 , with minimum value of 0 and maximum value of 0.05 . Which is highly low than the average ratio for Gender Diversity in the USA ( 0.1980 with minimum value of 0.06 and maximum value of 0.5).

Table 2. Summary for descriptive statistics of all the research variables for Egypt and the USA.

\begin{tabular}{ccc}
\hline Variables & Egypt & USA \\
\hline Board of Directors' Characteristics & & \\
DUAL & 0.6826 & 0.6667 \\
Mean & 0.46685 & 0.47272 \\
Std. Deviation & 0.00 & 0.00 \\
Minimum & 1.00 & 1.00 \\
Maximum & & \\
BOIND & 0.5811 & 0.5332 \\
Mean & 0.27589 & 0.11426 \\
Std. Deviation & 0.00 & 0.27 \\
Minimum & 0.93 & 0.88 \\
Maximum & & \\
BOSIZE & 7.9657 & 8.0824 \\
Mean & 2.53458 & 2.08288 \\
Std. Deviation & 3.00 & 4.00 \\
Minimum & 15.00 & 11.00 \\
Maximum & & \\
\hline
\end{tabular}




\section{Continued}

$\begin{array}{ccc}\text { BOMEET } & & \\ \text { Mean } & 10.0460 & 8.7111 \\ \text { Std. Deviation } & 5.05326 & 3.71843 \\ \text { Minimum } & 3.00 & 3.00 \\ \text { Maximum } & 25.00 & 19.00 \\ \text { GENDIV } & & \\ \text { Mean } & 0.0569 & 0.1980 \\ \text { Std. Deviation } & 0.09760 & 0.08793 \\ \text { Minimum } & 0.00 & 0.06 \\ \text { Maximum } & 0.05 & 0.50\end{array}$

\section{Control Variables}

\section{FISIZE}

Mean
Std. Deviation
Minimum
Maximum
FAGE

2.8743

5.0107

0.81553

0.60427

0.95

1.66

4.64

6.41

Mean

1.3155

1.9863

Std. Deviation

Minimum

0.34950

1.7338

Maximum

0.00

1.2553

1.89

2.3324

\section{FLEV}

Mean

Std. Deviation

0.5299

3.5134

1.74077

1.48820

Minimum

0.00

.04

Maximum

27.36

4.67

SG

Mean

Std. Deviation

$-0.5660$

0.0979

2.64653

2.88017

Minimum

$-4.95$

$-1.00$

Maximum

11.45

21.19

CF

$$
\text { Mean }
$$

Std. Deviation

Minimum

Maximum

0.6050

0.3475

7.30943

3.72252

$-0.30$

0.20

11.831

45.62

DIND

Mean

Std. Deviation

Minimum

Maximum

7.00

1.313

5.00

4.49

1.00

1.00

18.00

5.00

\section{Tobin's Q}

Mean

Std. Deviation

Minimum

Maximum

$\begin{array}{cc}0.6980 & 3.1560 \\ 2.89323 & 5.11281 \\ 0.00 & 5.13 \\ 14.90 & 18.00\end{array}$




\subsection{Testing the Regression Assumptions}

In order to conduct the regression model, the data under study was tested and manipulated for some assumptions that are required for the ordinary least squares estimation (OLS). The Hausman test for fixed versus random effects for the Egyptian and the American samples showed that there is an insignificant difference between the random and fixed effects, as the corresponding P-value is greater than 0.05 . Also, the research variables in the model of study were manipulated to have approximate normality. In addition, the observed results for the Egyptian and the American data lead researchers to extract the residuals plot. The histogram with the normality plot for the Egyptian data, implies that data may be approximately normal, as there is no heavy tails nor steepness in the curve extracted. Also, the sample size is considered as large enough to accept approximate normality. While, the histogram with the normality plot for the American data, implies that data may not be approximately normal, as the skewness and kurtosis values are beyond the accepted level of \pm 1 , which means that the Generalized Least Squares estimation (GLS) is required for the research analysis. Furthermore, the Durbin Watson test for the Egyptian sample data, displayed that there is a problem of autocorrelation since this model test results are 1.493 in all stated models. While, for the American sample data, the model test results are greater than 2.019 in all stated models so, the null hypothesis of no autocorrelation is supported. This implies that there is no problem of autocorrelation. Moreover, the VIFs values of all of the research variables for the Egyptian and the American samples data were less than 10, which imply that there is no problem of multicollinearity between the research variables. Finally, the White's test shows that there is no heteroscedasticity problem in the model since the residuals are almost scattered and there is no noticeable pattern in the diagram for both of the Egyptian and the American data samples.

\subsection{Testing the Research Hypotheses}

This sub-section discusses the research hypotheses and test them using correlation and regression analysis. As mentioned before, five main hypotheses and ten sub hypotheses formulated and will be tested in the following section.

\subsubsection{Testing the First Hypothesis for the Relation between CEO Duality and Firm Value}

This sub section examines the relationship between CEO Duality (DUAL) and Firm Value (Tobin's Q). This relationship hypothesizing that there is a significant negative relationship between CEO Duality and Firm Value. The correlation matrix for the relationship between DUAL and the Egyptian listed firms' value, shown that there is a positive relationship between CEO duality and the Egyptian listed firms' value, as the correlation coefficient of $0.150(\mathrm{r}>0)$. Also, the regression model for the effect of CEO duality on the Egyptian listed firms' value, shown that there is a positive significant effect of CEO duality on the Egyptian listed firms' value, with coefficient of $0.639(\mathrm{r}>0)$, and the corres- 
ponding $\mathrm{P}$-value is less than $0.05(\mathrm{P}$-value $=0.030)$. The overall F-statistic is shown to be 4.777 . In addition, $\mathrm{R}$ Square is 0.022 , which means that CEO duality explains $2.2 \%$ of the variation in the Egyptian Firms' Value. These results are supported by Amer [9]. But opposing to Carter et al. [59]. Thus, the first sub hypothesis of the first hypothesis that there is a significant negative relationship between CEO Duality and the Egyptian Listed Firms' value is not supported. Opposing to the Egyptian results the correlation matrix for the relationship between DUAL and Tobin's Q in the American sample, displayed that there is a negative relationship between CEO duality and the American listed firms' value, as the correlation coefficient of $-0.1834(\mathrm{r}<0)$. In addition, the regression model for the effect of CEO duality on the American listed firms' value, displayed that there is a negative significant effect of CEO duality on the American listed firms' value, with coefficient of -0.6348 and the corresponding $\mathrm{P}$-value is less than 0.05 (P-value $=0.000)$. The overall F-statistic is shown to be 1.8802 . In addition, $\mathrm{R}$ Square is 0.033 , which means that CEO duality explains $3.3 \%$ of the variation in the American listed firms' value. This result comes in consistence with Switzer and Tang [60]. But it is opposite to Gill and Obradovich [61] Thus, the second sub hypothesis of the first hypothesis that there is a significant negative relationship between CEO Duality and the American listed firms' value is supported. Consequently, the first hypothesis that there is a significant negative relationship between CEO Duality and firm value is partially supported.

\subsubsection{Testing the Second Hypothesis for the Relation between Board Independence and Firm Value}

This sub section examines the relationship between Board Independence (BOIND) and Firm Value (Tobin's Q). This relationship hypothesizing that there is a significant positive relationship between Board Independence and Firm Value. The correlation and regression analysis were conducted to respond to the research hypothesis. The correlation matrix for the relationship between board independence and the Egyptian listed firms' value, revealed that there is a positive relationship between board independence and the Egyptian listed firms' value, as the correlation coefficient is 0.535748 ( $\mathrm{r}>0$ ). In addition, the regression model for the effect of board independence on the Egyptian listed firms' value, revealed that there is a significant positive effect of board independence on the Egyptian listed firms' value, with coefficient of 0.923617 and the corresponding $\mathrm{P}$-value is less than $0.05(\mathrm{P}$-value $=0.000)$. The overall F-statistic is shown to be 83.33321 . In addition, $\mathrm{R}$ Square is 0.287 , which means that Board Independence explains $28.7 \%$ of the variation in the Egyptian listed firms' value. Board independence result comes in accordance with Carter et al. [59] and Asante-Darko et al. [37]. Whereas, it contrasts to Nashlaji and Ghanadi [10] and Singh et al. [62]. Thus, the first sub hypothesis of the second hypothesis that there is a significant positive relationship between Board independence and the Egyptian listed firms' value is supported. In the other side, the correlation matrix for the relationship between board independence and firm value in the Ameri- 
can sample shown that there is a positive relationship between board independence and the American listed firms' value, as the correlation coefficient is $0.6996(r>0)$. Consistent with what was found in the Egyptian sample, the regression model for the effect of board independence on the American listed firms' value shown that there is a significant positive effect of board independence on the American listed firms' value, with coefficient of 0.883 and the corresponding $\mathrm{P}$-value is less than $0.05(\mathrm{P}$-value $=0.000)$. The overall F-statistic is shown to be 311.1403 . In addition, $\mathrm{R}$ Square is 0.489 , which means that Board Independence explains $48.9 \%$ of the variation in the Firm Value. Thus, the second sub hypothesis of the second main hypothesis that there is a significant positive relationship between Board independence and the American listed firms' value is supported. Accordingly, the second hypothesis that there is a significant positive relationship between board independence and firm value is fully supported.

\subsubsection{Testing the Third Hypothesis for the Relation between Board Size and Firm Value}

This sub section examines the relationship between Board Size (BOSIZE) and Firm Value (Tobin's Q). This relationship hypothesizing that there is a significant negative relationship between Board Size and Firm Value. The correlation matrix for the relationship between Board Size and Firm Value in the Egyptian sample, exposed that there is a negative relationship between Board Size and the Egyptian listed firms' value, as the corresponding correlation coefficient is $-0.194(\mathrm{r}<0)$. Also, the regression model for the effect of Board Size on the Egyptian listed firms' value, exposed that there is a significant negative effect of Board Size on the Egyptian listed firms' value, with coefficient of -0.3133 and the corresponding $\mathrm{P}$-value is less than 0.05 ( $\mathrm{P}$-value $=0.0036)$. The overall F-statistic is shown to be 8.676385 . In addition, $\mathrm{R}$ Square is 0.037 , which means that Board Size explains 3.7\% of the variation in the Egyptian listed firms' value. Board size results agree with Yermack [38], Gill and Obradovich [61] and Asante-Darko et al. [37]. On contrary, Ciftcia et al. [63] and Singh et al. [62] found a positive relationship between them. Thus, the first sub hypothesis of the third hypothesis that there is a significant negative relationship between BOSIZE and the Egyptian listed firms' value is supported. In the other side, the correlation matrix for the relationship between Board Size and Firm Value in the American sample, shown that there is a negative relationship between Board Size and the American listed firms' value, as the corresponding correlation coefficient is $-0.4634(r<0)$. Similar to what found in the Egyptian sample, the regression model for the effect of Board Size on the American listed firms' value, shown that there is a significant negative effect of Board Size on the American listed firms' value, with coefficient of -1.246 and the corresponding P-value is less than $0.05(\mathrm{P}$-value $=0.000)$. The overall F-statistic is shown to be 15.85661. In addition, $\mathrm{R}$ Square is 0.215 , which means that Board Size explains $21.5 \%$ of the variation in the American listed firms' value. Thus, the second sub hypothesis of 
the third hypothesis that there is a significant negative relationship between board size and the American listed firms' value is supported. Therefore, the third hypothesis that there is a significant negative relationship between board size and firm value is fully supported.

\subsubsection{Testing the Fourth Hypothesis for the Relation between Board Meetings and Firm Value}

This sub section examines the relationship between Board Meetings (BOMEET) and Firm Value (Tobin's Q). This relationship hypothesizing that there is a significant positive relationship between Board Meetings and Firm Value. The correlation matrix for the relationship between Board meetings and Firm Value in the Egyptian sample, displayed that there is a positive relationship between Board meetings and the Egyptian listed firms' value, as the correlation coefficient is $0.306148(r>0)$. In addition, the regression model for the effect of Board meetings on the Egyptian listed firms' value, displayed that there is a significant positive effect of Board meetings on the Egyptian listed firms' value, with coefficient of 0.1950 and the corresponding P-value is less than 0.05 . In addition, $\mathrm{R}$ Square is 0.0937 , which means that Board meetings explains $9.3 \%$ of the variation in the Egyptian listed firms' value. Board meetings results comes in line with Vafeas [42] but, on the opposite to, Yermack [38]. Thus, the first sub hypothesis of the fourth hypothesis that there is a significant positive relationship between Board Meetings and the Egyptian listed firms' value is supported. In the other side, the correlation matrix for the relationship between Board meetings and Firm Value in the American sample, presented that there is a positive relationship between Board meetings and the American listed firms' value, as the correlation coefficient is $0.5293(\mathrm{r}>0)$. As what was found in the Egyptian sample, the regression model for the effect of Board meetings on the American listed firms' value, presented that there is a significant positive effect of Board meetings on the American listed firms' value, with coefficient of 0.442 and the corresponding P-value is less than 0.05 . The overall F-statistic is shown to be 22.5692. In addition, $\mathrm{R}$ Square is 0.28 , which means that Board meetings explains $28 \%$ of the variation in the American listed firms' value. Thus, the second sub hypothesis of the fourth hypothesis that there is a significant positive relationship between Board Meetings and the American listed firms' value is supported. As a result, the fourth hypothesis that there is a significant positive relationship between board meetings and firm value is fully supported.

\subsubsection{Testing the Fifth Hypothesis for the Relation between Gender Diversity and Firm Value}

This sub section examines the relationship between Gender Diversity (GENDIV) and Firm Value (Tobin's Q). This relationship hypothesizing that there is a significant positive relationship between gender diversity and Firm Value. The correlation matrix for the relationship between Gender diversity and Firm Value in the Egyptian sample, displayed that there is a positive relationship between Gender diversity and the Egyptian listed firms' value, as the correlation coeffi- 
cient is $0.2759(\mathrm{r}>0)$. Also, the regression model for the effect of Gender diversity on the Egyptian listed firms' value, displayed that there is a significant positive effect of Gender diversity on the Egyptian listed firms' value, with coefficient of 0.8045 , and the corresponding P-value is less than 0.05. In addition, R Square is 0.0761 , which means that Gender diversity explains $7.6 \%$ of the variation in the Egyptian listed firms' value. Gender diversity results supported by Levi et al. [43] and Terjesen et al. [45] but not supported by, Hassan and Marimuthu [46] and Iren [18]. Thus, first sub hypothesis of the fifth hypothesis that there is a significant positive relationship between Gender Diversity and the Egyptian listed firms' value is supported. in the other side, the correlation matrix for the relationship between Gender diversity and Firm Value in the American sample, shown that there is a positive relationship between Gender diversity and the American listed firms' value, as the correlation coefficient is $0.098(r>0)$. Like what was found in the Egyptian sample, the regression model for the effect of Gender diversity on the American listed firms' value, shown that there is a significant positive effect of Gender diversity on the American listed firms' value, with coefficient of 4.899, and the corresponding P-value is less than 0.05 . In addition, $\mathrm{R}$ Square is 0.0197 , which means that Gender diversity explains $2 \%$ of the variation in the American listed firms' value. Thus, the second sub hypothesis of the fifth hypothesis that there is a significant positive relationship between Gender Diversity and the American listed firms' value is supported. As a result, the fifth hypothesis that there is a significant positive relationship between gender diversity and firm value is fully supported.

\subsubsection{Testing the Relation between the Research Control Variables and Firm Value}

By reasons of coefficients and significance it was found that there is a positive significant relationship between the financial leverage, sales growth and cash flows and the Egyptian listed firms' value as the coefficient is more than zero and $\mathrm{P}$-value is less than 0.05 . While there is a positive insignificant effect of firm size in their firm value. In addition, there is a negative insignificant effect of firm age and the industry type on the Egyptian listed firms' value as the coefficient is less than zero and P-value is more than 0.05. In the other side, it was found that there are positive significant relationships between firm age and the financial leverage and the American listed firms' value as the coefficient is more than zero and P-value is less than 0.05. Whereas, there are positive insignificant effects of firm size, cash flow and the industry type on their firm value. Finally, there is a negative insignificant effect of sales growth on the American listed firms' value as the coefficient is less than zero and P-value is more than 0.05 .

\subsection{Testing the Whole Model}

The current section is designed to test the whole model together with the independent variables and then after adding the control variables using multiple regression analysis. 


\subsubsection{Testing the Relation between Board of Director's Characteristics and Firm Value}

The regression model for the effect of the Board of director's characteristics on Firm Value in the Egyptian sample indicated that there is a negative significant effect of Board Size, while there is positive significant effect of CEO Duality, Board Independence, Board Meetings, and Gender diversity on Firm Value, as the corresponding P-values are less than 0.05 , and the regression coefficients are $0.5603,0.8399,0.1019$, and 0.8484 respectively. In addition, R Square is 0.402, which means that Board of director's characteristics explain $40.2 \%$ of the variation in Firm value. Therefore, the regression equation could be formulated as follows:

$$
\begin{aligned}
\text { Tobin's } \mathrm{Q}= & 1.2186+0.5603 * \text { DUAL }+0.8399 * \text { BOIND } \\
& -0.2054 * \text { BOSIZE }+0.1019 * \text { BOMEET } \\
& +0.8484 * \text { GENDER }
\end{aligned}
$$

In the other side, the regression model for the effect of the Board of director's characteristics; CEO duality, board independence, Board size, Board meetings, and Gender diversity on Firm Value in the American sample, indicated that there is a negative significant effect of CEO duality and Board Size while there is positive significant effect of Board Independence, Board Meetings and Gender Diversity on the American listed firms' value, as the corresponding P-values are less than 0.05 , and the coefficient is -0.747 . In addition, $R$ Square is 0.627 , which means that Board of director's characteristics explain $62.7 \%$ of the variation in the American listed firms' value. Therefore, the following equation expresses the relationship:

$$
\begin{aligned}
\text { Tobin's } \mathrm{Q}= & -0.747-0.291720 * \mathrm{DUAL}+0.587083 * \mathrm{BOIND} \\
& -0.747492 * \mathrm{BOSIZE}+0.254733 * \mathrm{BOMEET} \\
& +6.909422 * \text { GENDIV }
\end{aligned}
$$

\subsubsection{Testing the Relation between Research and Control Variables and Firm Value}

The regression model for the effect of the Board of director's characteristics and Control Variables on Firm Value in the Egyptian sample shows a positive significant effect of CEO duality, Board independence, Board Meetings, Gender Diversity, Financial Leverage, Sales Growth and Cash Flow on the Egyptian listed firms' value, as the corresponding P-value is less than 0.05 , and the regression coefficients are greater than zero. Also, it was found that there is a negative significant effect of Board Size on the Egyptian listed firms' value, as the corresponding P-value is less than 0.05 , and the regression coefficients is less than zero. In the other hand, there is an insignificant effect of the Control Variables; Firm Size, Firm Age and Industry Type on the Egyptian listed firms' value, as $\mathrm{p}$-value is more than 0.05 . In addition, $\mathrm{R}$ Square is 0.544 , which means that Board of director's characteristics in the existence of the control variables model explain $54.4 \%$ of the variation in the Egyptian listed firms' value. Therefore, the regression equation could be formulated as follows: 


$$
\begin{aligned}
\text { Tobin's } \mathrm{Q}= & -0.1975+0.4087 * \mathrm{DUAL}+0.816 * \mathrm{BOIND}-0.0959 * \mathrm{BSIZE} \\
& +0.0474 * \mathrm{BMEET}+0.6231 * \mathrm{GENDIV}+0.744 * \mathrm{FISIZE} \\
& -0.9219 * \mathrm{FAGE}+3.4754 * \mathrm{FLEV}+0.215 * \mathrm{SG}+4.400 * \mathrm{CF} \\
& -0.090 * \mathrm{DIND}
\end{aligned}
$$

In the other side, the regression model for the effect of the Board of director's characteristics with Control Variables on Firm Value in the American sample displayed a significant positive effects of Board Independence, Board Meetings, Gender Diversity, Firm Age and Financial Leverage on the American listed firms' value, as the corresponding $\mathrm{P}$-values are less than 0.05 , and the regression coefficients are greater than zero. Also, it was found that there is a negative significant effect of Board Size on the American listed firms' value, as the corresponding P-values are less than 0.05, and the regression coefficients are less than zero. Furthermore, it was found that there is a positive insignificant effect of Firm Size, Cash Flow and the Industry Type on the American listed firms' value, as the corresponding $\mathrm{P}$-values are more than 0.05 , and the regression coefficients are more than zero. Moreover, it was found that there is a negative insignificant effect of sales growth on the American listed firms' value, as the corresponding $\mathrm{P}$-values are more than 0.05 , and the regression coefficients are less than zero. In addition, R Square is 0.709, which means that Board of director's characteristics in the existence of the control variables explain $70.9 \%$ of the variation in Firm value. Therefore, the regression equation could be formulated as follows:

$$
\begin{aligned}
\text { Tobin's } \mathrm{Q}= & 2.6264-0.7212 * \mathrm{DUAL}+0.63808 * \mathrm{BOIND}-0.5059 * \mathrm{BSIZE} \\
& +0.2026 * \mathrm{BMEET}+14.4247 * \mathrm{GENDIV}+0.1067 * \mathrm{FISIZE} \\
& +5.8734 * \mathrm{FAGE}+6.8779 * \mathrm{FLEV}-0.0009 * \mathrm{SG}+18.3641 * \mathrm{CF} \\
& +0.3262 * \mathrm{DIND}
\end{aligned}
$$

To review the results of the regression model of the board of directors characteristics (independent variables) against the firm value (Tobin's Q), it is apparent that most of the hypotheses formulated earlier were supported by reason of coefficients and significance. Table 3 summarizes the results of testing the research hypotheses and whether they were accepted or rejected. It should be noticed that there are nine hypotheses (H1b), (H2a), (H2b), (H3a), (H3b), (H4a), (H4b), $(\mathrm{H} 5 \mathrm{a})$ and $(\mathrm{H} 5 \mathrm{~b})$ supported whereas there is only one hypothesis (H1a) not supported. Consequently, it demonstrates that there is a consistency between current and previous research regarding most of the characteristics of the board of directors under study and firm value.

\section{Conclusion}

The research overall results showed that board of directors' characteristics affects firm value nearly in the same way on both Egypt and the USA. The results presented that board independence, board meetings and gender diversity are positively and significantly correlated to firm value in both countries. In the other hand, the results displayed that the CEO duality has positive effects on firm value in the Egyptian context whereas it has a negative effect on the firm value in the 
Table 3. Results summary.

\begin{tabular}{|c|c|c|}
\hline Hypothesis & Description & Results \\
\hline H1 & $\begin{array}{l}\text { There is a significant negative relationship between CEO } \\
\text { duality and firm value. }\end{array}$ & Partially supported \\
\hline H1a & $\begin{array}{l}\text { There is a significant negative relationship between CEO } \\
\text { duality and the Egyptian listed firms' value. }\end{array}$ & Not supported \\
\hline $\mathrm{H} 1 \mathrm{~b}$ & $\begin{array}{l}\text { There is a significant negative relationship between CEO } \\
\text { duality and the American listed firms' value. }\end{array}$ & supported \\
\hline $\mathrm{H} 2$ & $\begin{array}{l}\text { There is a significant positive relationship between board } \\
\text { independence and firm value. }\end{array}$ & Fully supported \\
\hline $\mathrm{H} 2 \mathrm{a}$ & $\begin{array}{l}\text { There is a significant positive relationship between board } \\
\text { independence and the Egyptian listed firms' value. }\end{array}$ & supported \\
\hline $\mathrm{H} 2 \mathrm{~b}$ & $\begin{array}{l}\text { There is a significant positive relationship between board } \\
\text { independence and the American listed firms' value. }\end{array}$ & supported \\
\hline H3 & $\begin{array}{l}\text { There is a significant negative relationship between board } \\
\text { size and firm value. }\end{array}$ & Fully supported \\
\hline $\mathrm{H} 3 \mathrm{a}$ & $\begin{array}{l}\text { There is a significant negative relationship between board size } \\
\text { and the Egyptian listed firms' value. }\end{array}$ & supported \\
\hline $\mathrm{H} 3 \mathrm{~b}$ & $\begin{array}{l}\text { There is a significant negative relationship between board size } \\
\text { and the American listed firms' value. }\end{array}$ & supported \\
\hline $\mathrm{H} 4$ & $\begin{array}{l}\text { There is a significant positive relationship between board } \\
\text { meetings and firm value. }\end{array}$ & Fully supported \\
\hline $\mathrm{H} 4 \mathrm{a}$ & $\begin{array}{l}\text { There is a significant positive relationship between Board } \\
\text { meetings and the Egyptian listed firms' value. }\end{array}$ & supported \\
\hline $\mathrm{H} 4 \mathrm{~b}$ & $\begin{array}{l}\text { There is a significant positive relationship between Board } \\
\text { meetings and the American listed firms' value. }\end{array}$ & supported \\
\hline H5 & $\begin{array}{l}\text { There is a significant positive relationship between gender } \\
\text { diversity and firm value. }\end{array}$ & Fully supported \\
\hline $\mathrm{H} 5 \mathrm{a}$ & $\begin{array}{l}\text { There is a significant positive relationship between gender } \\
\text { diversity and the Egyptian listed firms' value. }\end{array}$ & supported \\
\hline $\mathrm{H} 5 \mathrm{~b}$ & $\begin{array}{l}\text { There is a significant positive relationship between gender } \\
\text { diversity and the American listed firms' value. }\end{array}$ & supported \\
\hline
\end{tabular}

American context. Finally, the board size is negatively and significantly associated with firm value in both Egypt and the USA. These relationships play an important role in defining whether or not a specific characteristic is valuable to firms. By means of so, the research specified the critical importance of the constitution of the board of directors in order to improve the firms' value. These results are surprising if it is a-priori expected, supposing that it should weigh more as we move toward the best practice of investor protection found in Anglo-American financial markets. However, the same results found in the Egyptian firms in all the board of directors' characteristics under the current study except the CEO duality results were compared to the USA as illustrated above. It reflects that, the revised Corporate Governance Code for listed companies by the EIOD in 2011, in quest of keeping up to date with the best practices at the inter- 
national and regional levels, in terms of the roles of Boards of directors, comes with more developments in corporate governance in Egypt.

\section{Research Limitations and Recommendations}

The main limitations of this study are the sample and data limitations. Even so, significant measures were used to guarantee that this research's objectives were met and that its research question was answered. Since 2012 to 2017 chosen as a time period of the study to reveal the impact of the latest developments in corporate governance in Egypt on firm value after the EIOD revision of the Corporate Governance Code for listed companies in March 2011, in pursuit of keep up to date with the best practices at the international and regional levels, in terms of the roles of boards of directors [17], and because of all companies listed in the EGX committed to disclose all the information related to their board of directors in an annual board of directors report since 2014 (EGX report, 2014), as a result the researcher found a problem of data availability before 2014. Consequently, the sample of the study is limited to listed firms in the EGX for a certain assumption as mentioned before like the availability of a comprehensive and relevant corporate governance data, which means that the sample of the study was not chosen randomly. Also, the American sample size of this study is small. This study is limited to the American firms listed on DJIA. Therefore, the findings of this study could only be generalized to firms similar to those that were included in this index. In addition, because there is a limited amount of accessible information, other features of directors' board such as family members in the board, dependence on other companies, and so on were not examined. Finally, the current empirical analyses are based on a single country setting (Egypt as an example for an emerging country and USA as an example for a developed country) therefore, testing the inferences regarding board of directors' characteristics and firm value in a multi-country context would give additional support to the research findings.

The results of this research have implications for setting standards and contribute to the continuous argument of whether or not it would be possible to coordinate corporate governance practices around the world. For example, one of the critical themes of recent corporate governance developments in the developed countries, is for one individual not to be both the CEO and the chairman of the board. As recommended by the agency theory that CEO duality is bad for performance because it conciliations the monitoring and control of the CEO. This study recommends that the EGX firms have the roles of CEO and chairman held together. This is because researchers found positive effects in firm value resulting from CEO duality. But boards should be alert for agency issues (e.g., pursuit of CEO self-interests) which are likely to occur in firms with CEO duality. Therefore, one implication from this research is drawing the attention of corporate governance regulators in the Egyptian market regarding CEO duality. Moreover, the research found a negative association between the board size and 
a firm's value in both countries. Accordingly, this research finds that a board of more directors will negatively affect the firm's value in Egypt. Based on this result this research gives a recommendation to firms listed on EGX that a board of more directors will be unbeneficial for firm value, and it might be an extra cost from the agency theory perspective. In addition, the most important result of this research is, the existence of women in the board of director has a significant positive impact on the firm value in Egypt and also in the USA. As illustrated by Levi et al. [43] that the existence of women aids to generate shareholder value for the reason that they give the impression to be less dedicated to build economic empires, which in maximum cases are appreciated with the inefficient over consumption of corporate resources, and consequently permit firms to save resources that can be used in an investment projects that are more profitable. Accordingly, the authorities of corporate governance should put regulations to encourage companies to permit more proportion of women to exist in the board to improve their firm value and to command these recommendations. Additionally, unlocking facts relating to the practice of businesses in a region like Egypt that is characterized by a private culture and unwillingness to disclose information and dominated by family businesses, is vital to many International organizations (e.g., OECD), regulators, government bodies, and standards setters, to signal to those parties the importance of continuing their efforts in reforming and promoting investor protection, transparency and disclosure measures in order to improve the efficiency of financial markets and enhance investor confidence. Moreover, built on the above discussion, researchers recommend that empirical evidence from studies as such should be the baseline for current corporate governance codes and recommendations. Therefore, the most important implication of this research is to draw the attention of regulators to assessing the weaknesses in their corporate governance, as well as emphasizing other effective governance mechanisms that match their institutional and regulatory needs. Finally, the results of this research offer indication that some corporate governance characteristics are significantly related to a firm value. However, there are other important areas concerning corporate governance and its influence on firm value that were not enclosed by this research. Consequently, for future studies, it is recommended to study the effect of those other board characteristics such as, the proportion of family members in the board and the dependence on other companies on the firm value.

\section{Conflicts of Interest}

The authors declare no conflicts of interest regarding the publication of this paper.

\section{References}

[1] Loukas, J.S. (2004) Corporate Governance in Greece: Developments and Policy Implications. Center of Financial Studies, Department of Economics, University of 
Athens, Athens.

[2] Li, T. and Zaiats, N. (2018) Corporate Governance and Firm Value at Dual Class Firm. Review of Financial Economics, 36, 47-71. https://doi.org/10.1016/j.rfe.2017.07.001

[3] Nguyen, H., Rahman, N., Tong, A. and Zhao, R. (2015) Board Size and Firm Value: Evidence from Australia. Journal of Management and Governance, 20. https://doi.org/10.1007/s10997-015-9324-2

[4] Rakesh, K.M. and Sheeba, K. (2018) Effect of Board Characteristics on Firm Value: Evidence from India. South Asian Journal of Business Studies, 7, 41-72.

[5] Abdullah, S.N., Ismail, K.N. and Nachum, L. (2016) Does Having Women on Boards Create Value? The Impact of Societal Perceptions and Corporate Governance in Emerging Markets. Strategic Management Journal, 37, 466-476. https://doi.org/10.1002/smj.2352

[6] Dikeç, A., Kane, V. and Çapar, N. (2019) Cross-Country and Cross-Sector CSR Variations: A Comparative Analysis of CSR Reporting in the U.S., South Korea, and Turkey. Corporate Social Responsibility: Concepts, Methodologies, Tools, and Applications, 3, 28. https://doi.org/10.4018/978-1-5225-6192-7.ch078

https://www.igi-global.com/chapter/cross-country-and-cross-sector-csr-variations/ 207028

[7] Rubino, F.E., Tenuta, P. and Cambrea, D.R. (2016) Board Characteristics Effects on Performance in Family and Non-Family Business: A Multi-Theoretical Approach. Journal of Management and Governance, 21, 623-658.

[8] Dal Vesco, D.G. and Beuren, I.M. (2016) Do the Board of Directors Composition and the Board Interlocking Influence on Performance? Brazilian Administration Review, 13, e160007.

[9] Amer, M. (2016) Measuring the Effect of the Board of Directors and Audit Committee Characteristics on Firm Financial Performance in Egypt. Thesis, Cardiff Metropolitan University, Cardiff.

[10] Nashlaji, S.M. and Ghanadi, A.A. (2016) The Effect of Characteristics of Board of Directors on Financial Performance of Firms in Tehran Stock. International Journal of Humanities and Cultural Studies, Special May Issue, 1642-1657.

[11] Mutunga, M.J. (2015) The Effects of Board Profile on Financial Performance of Firms Listed at the Nairobi Securities Exchange. PhD Thesis, University of Nairobi, Nairobi.

[12] Anderson, R.C. and Reeb, D.M. (2004) Board Composition: Balancing Family Influence in Sand P 500 Firms. Administrative Science Quarterly, 49, 209-237.

[13] San Martin-Reyna, J.M. and Duran-Encalada, J.A. (2012) The Relationship among Family Business, Corporate Governance and Firm Performance: Evidence from the Mexican Stock Exchange. Journal of Family Business Strategy, 3, 106-117. https://doi.org/10.1016/j.jfbs.2012.03.001

[14] Adams, R.B. and Ferreira, D. (2009) Women in the Boardroom and Their Impact on Governance and Performance. Journal of Financial Economics, 94, 291-309. https://doi.org/10.1016/j.jfineco.2008.10.007

[15] De Andres, P., Azofra, V. and Lopez, F. (2005) Corporate Boards in OECD Countries: Size, Composition, Functioning and Effectiveness. Corporate Governance: An International Review, 13, 197-210.

[16] Samaha, K. (2010) Do Board Independence and Audit Committees Motivate Disclosure on Different Corporate Governance Information Categories in the Annual 
Reports in Developing Countries? International Research Journal of Finance and Economics, 57, 206-225.

[17] Shehata, N. and Dahawy, K. (2013) Review of the Implementation Status of Corporate Governance Disclosures: Egypt. United Nations Conference on Trade and Development.

[18] Iren, P. (2016) Gender Diversity of Boardrooms and Firm Financial Performance. Risk Governance and Control: Financial Markets and Institutions, 6, 30-35.

[19] Solomon, J. and Solomon, A. (2004) Corporate Governance and Accountability. John Wiley, New York.

[20] Rezaee, Z. (2009) Corporate Governance and Ethics. John Wiley and Sons, Hoboken.

[21] Rahman, N. (2008) An Investigation of the Association between Corporate Governance and Environmental Reporting in Malaysia. Asian Journal of Business and Accounting, 1, 639-647.

[22] OECD (2004) Principles of Corporate Governance. Organization for Economic Cooperation and Development, Paris.

[23] Egyptian Institute of Directors (EIOD) (2016) Egyptian Code of Corporate Governance. http://www.eiod.org

[24] Soliman, M. (2013) Corporate Governance and Earning Management: Evidences from Emerging Markets. LAP Lambert Academic Publishing.

[25] Egyptian Stock Exchange (2014) Stock Market Annual Report. http://www.egx.com.eg

[26] Smith, A. (1776) The Wealth of Nations. Book 4, Chapter 2, 401-402.

[27] Jensen, M.C. and Meckling, W.H. (1976) Theory of the Firm: Managerial Behavior, Agency Costs and Ownership Structure. Journal of Financial Economics, 3, 305-360. https://doi.org/10.1016/0304-405X(76)90026-X

[28] Fama, E.F. and Jensen, M.C. (1983) Separation of Ownership and Control. The Journal of Low and Economics, 26, 301-325.

[29] Daily, C.M., Dalton, D.R. and Canella, A.A. (2003) Corporate Governance: Decades of Dialogue and Data. Academy of Management Review, 28, 371-382. https://doi.org/10.5465/amr.2003.10196703

[30] Coleman, A., Adjasi, C. and Abor, J. (2007) Corporate Governance and Firm Performance: Evidence from Ghanaian Listed Companies. Corporate Ownership and Control, 4, 123-132.

[31] Pfeffer, J. and Salancik, G.R. (1978) The External Control of Organizations: A Resource Dependence Approach. Harper and Row Publishers, New York.

[32] Hillman, A.J., Canella, A.A. and Paetzold, R.L. (2000) The Resource Dependency Role of Corporate Directors: Strategic Adaptation of Board Composition in Response to Environmental Change. Journal of Management Studies, 37, 235-255. https://doi.org/10.1111/1467-6486.00179

[33] Muth, M. and Donaldson, L. (1998) Stewardship Theory and Board Structure: A Contingency Approach. Corporate Governance: An International Review, 6, 5-28.

[34] Freeman, R., Wicks, A. and Parmar, B. (2004) Stakeholder Theory and The-Corporate Objective Revisited. Organization Science, 15, 364-369. https://doi.org/10.1287/orsc.1040.0066

[35] Mitchell, R.K., Agle, B.R. and Wood, D.J. (1997) Toward a Theory of Stakeholder Identification and Salience: Defining the Principle of Who and What Really Counts. 
Academy of Management Review, 22, 853-886. https://doi.org/10.5465/amr.1997.9711022105

[36] Jenwittayroje, N. and Jiraporn, P. (2017) Do Independent Directors Improve Firm Value? Evidence from the Great Recession. International Review of Finance, 19, 207-222. https://onlinelibrary.wiley.com/doi/epdf/10.1111/irfi.12163 https://doi.org/10.1111/irfi.12163

[37] Asante-Darko, D., Bonsu, B.A., Famiyeh, S., Kwarteng, A. and YayraGoka, Y. (2018) Governance Structures, Cash Holdings and Firm Value on the Ghana Stock Exchange, Corporate Governance. The International Journal of Business in Society, 18, 671-685. https://doi.org/10.1108/CG-07-2017-0148

[38] Yermack, D. (1996) Higher Market Valuation of Companies with a Small Board of Directors. Journal of Financial Economics, 40, 185-211. https://doi.org/10.1016/0304-405X(95)00844-5

[39] Coles, J.L., Daniel, N.D. and Naveen, L. (2008) Boards: Does One Size Fit All? Journal of Financial Economics, 87, 329-356. https://doi.org/10.1016/j.jfineco.2006.08.008

[40] Vafeas, N. (1999) Board Meeting Frequency and Firm Performance. Journal of Financial Economics, 53, 113-142. https://doi.org/10.1016/S0304-405X(99)00018-5

[41] Carcello, J., Hermanson, D., Neal, T. and Riley, J. (2002) Board Characteristics and Audit Fees. Contemporary Accounting Research, 19, 365-384. https://doi.org/10.1506/CHWK-GMQ0-MLKE-K03V

[42] Vafeas, N. (2005) Audit Committees, Boards and the Quality of Reported Earnings. Contemporary Accounting Research, 22, 1093-1122. https://doi.org/10.1506/1QYN-2RFQ-FKYX-XP84

[43] Levi, M., Li, K. and Zhang, F. (2014) Director Gender and Mergers and Acquisitions. Journal of Corporate Finance, 28, 185-200. https://doi.org/10.1016/j.jcorpfin.2013.11.005

[44] Rhode, D.L. and Packel, A.K. (2014) Diversity on Corporate Boards: How Much Difference Does Difference Make? Delaware Journal of Corporate Law, 39, 377-426.

[45] Terjesen, S., Couto, E.B. and Francisco, P.M. (2016) Does the Presence of Independent and Female Directors' Impact Firm Performance? A Multi-Country Study of Board Diversity. Journal of Management and Governance, 20, 447-483. https://doi.org/10.1007/s10997-014-9307-8

[46] Hassan, R. and Marimuthu, M. (2016) Corporate Governance, Board Diversity, and Firm Value: Examining Large Companies Using Panel Data Approach. Economics Bulletin, 36, 1737-1750.

[47] O’Connor, T. (2012) Investability, Corporate Governance and Firm Value. Research in International Business and Finance, 26, 120-136. https://doi.org/10.1016/j.ribaf.2011.09.001

[48] Soliman, M.M. and Ragab, A.A. (2013) Board of Director's Attributes and Earning Management: Evidence from Egypt. Proceedings of 6 th International Business and Social Sciences Research Conference, Dubai, 3-4 January 2013, 1-20.

[49] Cheng, S. (2008) Board Size and the Variability of Corporate Performance. Journal of Financial Economics, 87, 157-176. https://doi.org/10.1016/j.jfineco.2006.10.006

[50] Andres, C. (2008) Large Shareholders and Firm Performance: An Empirical Examination of Founding Family Ownership. Journal of Corporate Finance, 14, 431-445. https://doi.org/10.1016/j.jcorpfin.2008.05.003

[51] Lee, J. (2009) Does Size Matter in Firm Performance? Evidence from US Public 
Firms. International Journal of the Economics of Business, 16, 189-203. https://doi.org/10.1080/13571510902917400

[52] Dittmar, A. and Mahrt-Smith, J. (2007) Corporate Governance and the Value of Cash Holdings. Journal of Financial Economics, 83, 599-634. https://doi.org/10.1016/j.jfineco.2005.12.006

[53] Ntim, C.G. (2016) Corporate Governance, Corporate Health Accounting, and Firm Value: The Case of HIV/AIDS Disclosure in Sub-Saharan Africa. The International Journal of Accounting, 51, 155-216.

[54] Chen, L. and Chen, S. (2011) The Influence of Profitability on Firm Value with Capital Structure as the Mediator and Firm Size and Industry as Moderators. Investment Management and Financial Innovations, 8, 121-129.

[55] Alsaeed, K. (2006) The Association between Firm-Specific Characteristics and Disclosure: The Case of Saudi Arabia. Journal of American Academy of Business, 7, 310-321.

[56] Hutcheson, G.D. and Sofroniou, N. (1999) The Multivariate Social Scientist: Introductory Statistics Using Generalized Linear Models. Sage, Thousand Oaks.

[57] Gaur, A.S. and Gaur, S.S. (2006) Statistical Methods for Practice and Research: A Guide to Data Analysis Using SPSS. Response Books, Sage Publication, New Delhi.

[58] Bhagat, S. and Black, B. (2002) Board Independence and Long-Term Performance. University of Colorado Working Paper.

[59] Carter, D.A., Simkins, B.J. and Simpson, W.G. (2003) Corporate Governance, Board Diversity, and Firm Value. The Financial Review, 38, 33-53.

[60] Switzer, L.N. and Tang, M. (2009) The Impact of Corporate Governance on the Performance of U.S. Small-Cap Firms. International Journal of Business, 14, 341-355.

[61] Gill, A. and Obradovich, J.D. (2012) The Impact of Corporate Governance and Financial Leverage on the Value of American Firms. International Research Journal of Finance and Economics, No. 91, 1-14.

[62] Singh, S., Tabassum, N., Darwish, T.K. and Batsakis, G. (2018) Corporate Governance and Tobin's Q as a Measure of Organizational Performance. British Journal of Management, 29, 171-190. https://doi.org/10.1111/1467-8551.12237

[63] Ciftcia, I., Tatoglub, E., Woodc, G., Demirbagc, M. and Zaimd, S. (2019) Corporate Governance and Firm Performance in Emerging Markets: Evidence from Turkey. International Business Review, 28, 90-103. https://doi.org/10.1016/j.ibusrev.2018.08.004 